\title{
EFFECT OF THE CULTURAL SYSTEM ON CORPORATE SOCIAL RESPONSIBILITY DISCLOSURE IN THE ENERGY SECTOR
}

\author{
Alan Bandeira Pinheiro 1 \\ Thicia Stela Lima Sampaio 2 \\ Daniel Barboza Guimarães 3 \\ Sílvia Maria Dias Pedro Rebouças ${ }^{4}$
}

- Received: 05/07/2021 -- Approved: 09/14/2021 -- Second Approved Version: 11/04/2021

\begin{abstract}
This study examines the effect of the cultural system on the disclosure of corporate social responsibility by companies in the energy sector. The survey analyzed a sample of 62 leading energy companies from 25 countries. The dependent variable is the level of environmental disclosure of the companies. The independent variables are composed by the cultural system of the analyzed countries, according to the Hofstede cultural dimensions. The data were analyzed using descriptive, inferential statistics, correlation, and regression of panel data. The findings show that in more individualistic and masculine cultures, companies disclose more CSR information. It was found that companies based in cultures with a higher level of indulgence and with a greater orientation for the long term tend to have greater environmental disclosure. The results show that the level of disclosure of corporate social responsibility is different depending on the country's cultural system. There are institutional pressures, which encourage companies to publish a more complete sustainability report. The results of this study have academic and managerial implications.
\end{abstract}

Keywords: Corporate Social Responsibility. Cultural System. Environmental Disclosure.

\footnotetext{
1 Master's degree in Management from Federal University of Ceará. Address: Av. da Universidade, 2431 - Benfica, Fortaleza - CE, 60020-180. Phones: (85) 3366-7803 / (85) 33667804. Email: alanbpinheiro@hotmail.com / alanbp@alu.ufc.br https://orcid.org/0000-0001-6326-575X

2 Master's degree in Accounting from Federal University of Ceará. Address: Av. da Universidade, 2431 - Benfica, Fortaleza - CE, 60020-180. Phones: (85) 3366-7803 / (85) 33667804. Email: thiciasampaio@gmail.com https://orcid.org/0000-0001-7105-9825
}

3 Associate Professor at Federal University of Ceará. Address: Av. da Universidade, 2431 Benfica, Fortaleza - CE, 60020-180. Phones: (85) 3366-7803 / (85) 3366-7804. Email: barbozadan@hotmail.com

https://orcid.org/0000-0001-6966-7194

4 Associate Professor at Federal University of Ceará. Address: Av. da Universidade, 2431 Benfica, Fortaleza - CE, 60020-180. Phones: (85) 3366-7803 / (85) 3366-7804. Email: smdpedro@gmail.com

https://orcid.org/0000-0002-8475-9748 


\section{EFEITO DO SISTEMA CULTURAL NA DIVULGAÇÃO DA RESPONSABILIDADE SOCIAL CORPORATIVA NO SETOR DE ENERGIA}

\section{RESUMO}

Este estudo examina o efeito do sistema cultural na divulgação da responsabilidade social corporativa por empresas do setor de energia. A pesquisa analisou uma amostra de 62 empresas líderes de energia de 25 países. A variável dependente é o nível de evidenciação ambiental das empresas. As variáveis independentes são compostas pelo sistema cultural dos países analisados, de acordo com as dimensões culturais do Hofstede. Os dados foram analisados por meio de estatística descritiva, inferencial, correlação e regressão de dados em painel. Os achados mostram que em culturas mais individualistas e masculinas, as empresas divulgam mais informações de RSC. Verificou-se que empresas baseadas em culturas com maior nível de indulgência e com maior orientação para o longo prazo tendem a ter maior evidenciação ambiental. Os resultados mostram que o nível de divulgação da responsabilidade social corporativa é diferente dependendo do sistema cultural do país. Existem pressões institucionais, que incentivam as empresas a publicar um relatório de sustentabilidade mais completo. Os resultados deste estudo têm implicações acadêmicas e gerenciais.

Palavras-Chave: Responsabilidade Social Corporativa. Sistema Cultural. Divulgação Ambiental.

\section{INTRODUCTION}

Firms have traditionally been conceived as profit-maximizing entities. However, in recent years, issues such as corporate governance, corporate ethics and corporate social responsibility (CSR) have gained ground in academic and business discussions, especially due to monumental corporate scandals (Abugre \& Anlesinya, 2020; Jamali, Safieddine \& Rabbath, 2008).

Therefore, corporate social responsibility is related to complex issues, such as environmental protection, relationship with the local community, suppliers and consumers, health, and safety at work (Branco \& Rodrigues, 2006). Thus, firms report the level of sustainability of their actions in sustainability reports, to improve the decision-making of stakeholders. However, the preparation of this type of information is expensive and requires the allocation of substantial funds (Li, Gong, Zhang \& Koh, 2018). Therefore, the adoption of disclosure practices is more recurrent in companies with a higher financial performance (Frias-Aceituno, Rodriguez-Ariza \& Garcia-Sanchez, 2012).

Several studies have found relationships between financial performance (Aboagye-Otchere, Simpson \& Kusi, 2019; Soares et al., 2018; Usman \& Amran, 2015), the sector of operation (Wanderley et al, 2008; Lock \& Seele, 2013) and corporate social responsibility disclosure. Although some researchers (Jensen \& Berg, 2012; Garcia-Sanchez, Cuadrado-Ballesteros \& Frias-Aceituno, 2016; Ferri, 2017; Oliveira, Rodrigues Junior, Lima \& Freitas, 2018; Coluccia, Fontana \& Solimene, 2018) have evidenced the effect of institutional pressures on CSR, few 
studies have evidenced the influence of a country's cultural system on the CSR disclosure, as it is more complex to measure informal institutions, such as the country's culture, traditions and unwritten codes of conduct.

Disclosure practices are different between countries with different cultural systems, since local stakeholders can exert different pressures (Carroll, 1979). In this context, the question that directs this research is: What is the effect of the national cultural system on the disclosure of corporate social responsibility in companies in the energy sector? Thus, this study aims to examine the effect of the cultural system on the disclosure of corporate social responsibility of companies in the energy sector.

The study of this sector is justified by being an environmentally sensitive sector (Miniaoui et al., 2019), because it deals directly with natural resources. As a result, the world's largest energy companies can cause major changes in the planet's natural ecosystem (Michelon, Pilonato, \& Ricceri, 2015; Stjepcevic \& Siksnelyte, 2017). Thus, analyzing only one country in relation to a sector may not seem significant, since the industries of the same country are of a similar size and follow the same social norms around the sector (Freedman \& Jaggi, 2009).

The research evaluated 62 energy companies on Fortune magazine's Global500 list (2019). The sample consists of companies from 25 countries for the period 2016-2018. As a dependent variable, 32 words were analyzed in the firms' environmental reports and the CSR index was calculated, according to the methodology used in Gamerschlag, Möller \& Verbeeten (2010). The independent variables represent the cultural system of the countries analyzed. These variables were extracted from Hofstede-insights (Hofstede, 1983). All these variables were tested in three econometric models of panel data using Logit regression, because the dependent variables of each of the models are dummy type.

The article presents four innovations: i) the potential conditions are theoretically and empirically identified, which the disclosure of CSR can be influenced in the largest companies in the energy sector in the world; ii) the present study analyzes the cultural context influencing the disclosure of corporate social responsibility in different locations, since previous studies, in general, have focused on the analysis of only one country (García-Sánchez, Rodríguez-Ariza \& Frías-Aceituno, 2013);; iii) the results can help policymakers' decisions on improving social responsibility in the energy sector; iv) this article adds independent variables not yet used to measure the cultural system of countries. Understanding how new variables affect CSR disclosure is important for managers to recognize which new institutional challenges can influence the environmental behavior of their industries.

The other sections of the article are structured as follows: section 2 presents an objective literature review, contemplating the stakeholder theory and the cultural system of the countries, as well as presenting the hypotheses tested in the econometric model. Section 3 presents in greater detail the methodology applied in the research. Section 4 presents the results obtained and the theoretical discussions and in section 5 the conclusions and contributions of the research are presented, as well as the limitations and suggestions for future studies. 


\section{LITERATURE REVIEW AND DEVELOPED HYPOTHESES}

Freeman (1984) defines stakeholder as any group or individual that affects or may be affected by the firm's performance. Thus, the stakeholders of a firm can be clients, investors, creditors, employees, community, media, among others. These stakeholders can be divided into two groups: Primary stakeholders: those in which their participation is fundamental to the company's business and Secondary stakeholders: those who do not directly deal with the company's productive activities (Clarkson, 1995). Thus, firms must know how to manage their stakeholders, since the dynamics of stakeholders can influence internal decisions in companies.

Therefore, each of the stakeholders forms heterogeneous groups, since they may present conflicting interests between themselves and in relation to the firm. For example, the interests of majority shareholders may not match the interests of minority shareholders. Just as some employees may only aim for a salary increase, other employees want power and professional satisfaction within the firm (Zubeltzu-Jaka, Andicoechea-Arondo \& Alvarez-Etxeberria, 2018). Given that modern corporations can benefit or harm crowds, firms should look to all stakeholders in decision making. Thus, the basic proposal of stakeholder theory is that the firm's survival depends on the management of relationships with stakeholders (García-Sánchez, Rodríguez-Ariza \& Frías-Aceituno, 2013).

Companies produce externalities that affect many parts, internal and external to the company. Thus, shareholders want to increase positive externalities and reduce negative externalities in order to meet the needs of stakeholders. Employees can press the firm for better working conditions, while the government can adopt rules and penalties to minimize environmental damage caused by firms. Thus, according to Sarkis, Gonzalez-Torre and AdensoDiaz (2010), stakeholder engagement is important for companies to establish social legitimacy. In addition, society's environmental education stimulates greater pressure for companies to reduce their environmental impacts (Pinheiro, Silva Filho \& Moreira, 2021).

The needs of shareholders will not be met without the needs of stakeholders being met as well. Thus, contrary to Friedman (2007), who states that the company's sole responsibility is to increase profits for shareholders. According to Jensen (2001), the company achieves its goals with the theory of maximizing shareholder wealth, as it is mathematically impossible to maximize in more than one direction. Thus, the author states that the stakeholder theory does not explain how managers can deal with the trade-off of interests of the various stakeholders. In fact, shareholders are the most important stakeholders of a firm. Without them, the firm would not exist.

However, the information provided in the financial reports for shareholders is not always sufficient. Thus, corporate transparency is expanded for all stakeholders and other areas, for example, corporate social responsibility, with the use of environmental reports. In this context, corporate social responsibility practices are influenced by stakeholder pressures (Helmig, Spraul \& Ingenhoff, 2016). Large companies have a greater number of stakeholders, given their visibility and power of influence in society (Roberts, 1992). Therefore, these large companies can make high investments in social responsibility to legitimize their 
commercial activity in the face of stakeholder pressures (Pinheiro, Costa \& Sampaio, 2021).

One of the ways to legitimize the firm's actions is the publication of environmental reports (Branco \& Rodrigues, 2006). After the 2008 financial crisis, CSR reports were established as a complement to corporate financial reports (Helmig, Spraul \& Ingenhoff, 2016). The disclosure of corporate social responsibility can be understood as the process of communicating social, economic, and environmental impacts to stakeholders (Gray, Owen \& Adams, 1996). More information in sustainability reports can relate to more informed decisions to stakeholders, as well as can influence the value of the company in a positive way.

Social and environmental disclosure practices can be influenced by the national context in which companies are inserted (Pinheiro et al., 2020). Thus, depending on the configuration of the National Business System, firms can highlight their environmental practices more explicitly or implicitly (Matten \& Moon, 2008). Given this, a country's culture influences many aspects of corporate decisions (Mohamed Adnan, Hay \& Van Staden, 2018). In this sense, the cultural differences between countries explain the similarities and differences of thought of a society and imply specific pressures from stakeholders in relation to the disclosure of corporate social responsibility (Soares et al., 2018).

\subsection{Hypotheses Developed}

Unlike the study conducted by Gamerschlag, Moller and Verbeeten (2010) that contemplated a single country, in order to maintain a homogeneity in the capitalist, political and social system of the sample components, this study aims to capture a sample in different social and political contexts, in addition to different levels of economic development. Thus, the independent variables that characterize these different contexts do not vary year by year, except for the country risk variable.

The different cultural characteristics or values of a society play an important role in business decisions and actions, especially in the field of corporate social responsibility. Therefore, Hofstede (2001) proposed a model with six dimensions that measure the cultural system of 93 countries. The dimensions are distance to power, individualism/collectivism, masculinity/femininity, aversion to uncertainty, long-term orientation, and indulgences/restrictions. This model has received a lot of attention in research on corporate social responsibility in different institutional contexts (Cubilla-Montilla et al., 2019).

The distance to power describes the perception of the social hierarchy in terms of equality and inequality (García-Sánchez et al., 2013). In countries with great distance to power the levels of command are stratified, presenting different hierarchies of power. On the other hand, countries with less distance from power are less hierarchical and more concerned with legitimacy (Hofstede, 1983) and have a balance in the distribution of power (Cabeza-García et al., 2019). In companies, the distance to power is measured by the degree of hierarchy and centralization of (Oliveira et al., 2018). Therefore, in countries with low distance to power, companies will be more concerned with meeting the 
expectations of all stakeholders, not only shareholders, seeking to legitimize their actions through environmental reports.

H1: Ceteris paribus, the level of CSR disclosure is negatively influenced by the distance to the power of the country (PWD).

In individualistic societies, people expect each one to take care of himself, that is, everyone thinks of his own interests. On the other hand, in collectivist countries, people are concerned about the group to which they belong (Hofstede, 1983). Stakeholders present in individualistic societies are more selfcentered (Garcia-Sanchez et al., 2016). In these societies there is a strong development of individual rights (García-Sánchez et al., 2013) and the word "I" is indispensable in the discourse (de Mooij \& Hofstede, 2010). From this perspective, firms present in individualistic companies will carry out fewer sustainability actions (Cubilla-Montilla et al., 2019). Thus, companies located in individualistic environments are not open to the dissemination of environmental information (Jensen \& Berg, 2012).

H2: Ceteris paribus, the level of CSR disclosure is negatively influenced by the individualism of the country (IND).

The dimension of masculinity/femininity refers to the role played by the sexes within society (Cubilla-Montilla et al., 2019). Male cultures are usually more assertive, strong and competitive. On the other hand, female cultures are based on cooperation, modesty and consensus (Hofstede, 1983) and there is a balance between family and work (Hofstede, 2011). While women's societies are focused on quality of life, male societies are focused on recognition and challenges (García-Sánchez et al., 2013). According to Scholtens \& Dam (2007) masculinity is negatively related to business ethics. Gallén \& Peraita (2017) found that companies in more female countries disclose more environmental information.

H3: Ceteris paribus, the level of CSR disclosure is negatively influenced by the country's masculinity (MSC).

The aversion to uncertainty represents a determining variable when studying the dissemination of CSRs. In societies with a strong aversion to uncertainty, the uncertainty inherent in life is felt as a continuing threat that must be combated. On the other hand, in societies with low aversion to uncertainty, there is a tolerance for people and new ideas, since the different is curious (Hofstede, 2011). In companies with low aversion to uncertainty, companies are more committed to sustainability (Garcia-Sanchez et al., 2016). Thus, in countries with greater aversion to uncertainty, companies will disclose less corporate social responsibility information (Esteban, Villardón \& Sánchez, 2017).

H4: Ceteris paribus, the level of CSR disclosure is negatively influenced by the country's aversion to uncertainty (UNAC).

The dimension of long-term guidance can be interpreted as society's search for virtue. Individuals with long-term guidance believe that truth depends on situation, context, and time (Garcia-Sanchez et al., 2016). Long-term oriented societies are characterized by considering that the most important events will occur in the future (Hofstede, 2011). On the other hand, cultures with short-term guidance waste considerable time developing (Cubilla-Montilla et al., 2019). Thus, companies located in countries with long-term guidance have a vision of continuity of the company (Jensen \& Berg, 2012). These companies prefer to 
release integrated reports involving corporate social responsibility practices than to disclose only a traditional financial report (Garcia-Sanchez et al., 2016).

H5: Ceteris paribus, the level of CSR disclosure is positively influenced by the country's long-term orientation (LTOR).

Indulgence represents a society that allows relatively free satisfaction of basic human desires. In countries with a high rate of indulgence, people allow themselves to enjoy more time with pleasurable activities. Indulgent cultures often have lower scores in moral disciplines and do not have a strong will to follow norms (Hofstede, 2011). In indulgent countries, companies perform fewer corporate social responsibility practices. In these contexts, companies are more oriented to shareholders (Sun et al., 2019). Therefore, companies located in indulgent environments do what the norms are, not worrying about actions, such as social and environmental disclosure, which is voluntary and oriented to the demands of stakeholders.

H6: Ceteris paribus, the level of CSR disclosure is positively influenced by the lowest levels of indulgences in the country (INDG).

The variables to characterize the legal system are four: common law, civil law, mixed and religion. This categorization has its theoretical basis in the dichotomy of the legal system that are used in the world: civil law e common law (Othman \& Zeghal, 2006). Civil law is the oldest and most used in the world. It originates in Roman law and uses codes to control, among other things, economic activity. On the other hand, there is common law, which originated in England. In this case, the law is composed of judges in charge of resolving disputes based on previous judicial decisions (La Porta et al., 1998). In addition, there is the mixed legal system, which has characteristics of the common law and civil law system. Finally, the legal system based on religion, common in countries of Islamic (sharia) and Muslim religion, has no separation between law and religion (Reimann \& Zimmermann, 2019).

While countries with civil law focus on the interests of stakeholders, common law ones focus on the interests of shareholders (Kolk \& Perego, 2010), and therefore generally develop laws to protect the rights of investors (GarciaSanchez et al., 2016). In civil law systems, companies adopt greater CSR practices (Coluccia et al., 2018), because it's common to find laws that describe how companies should act (Miniaoui et al., 2019). Previous research has pointed out a positive relationship between the civil law system and the disclosure of corporate social responsibility (Jensen \& Berg, 2012; Kolk \& Perego, 2010; Smith et al., 2005).

H7: Ceteris paribus, the level of CSR disclosure is positively influenced by the country's civil law system (LEGALS).

In order to give a communication profile to each country of the sample, these were allocated into two categories: high context or low context. These variables refer to the cultural profile obtained based on data from the Hofstedeinsights site, because according to Hall (1959), culture is communication and communication is culture. Thus, countries with the type of high context communication are characterized by the emphasis on human relations and more sensitivity of people to feelings. Thus, in these countries CSR practices will be 
more prevalent. On the other hand, low context countries have accurate and specific communication.

Due to the existence of these two extreme poles of communication profile Hall (1992) and Sorrells (1998) proposed four factors that impact on the definition of the level of communication in a country: cultural anthropology, linguistics, ethology (the study of animal behavior) and Freudian psychoanalytic theory. According to Hall's work (1959), these four factors can identify how much context and time (chronology) can influence the overlap of nonverbal communication (tone, expressions, and gestures) on verbal communication. Thus, it is believed that the communication system adopted by a country affects the social responsibility of its companies.

H8: Ceteris paribus, CSR disclosure level is positively influenced by high context communication system (CMICS).

The risk-country variable aims to give a macroeconomic aspect to the study considering that the factors of uncertainty and opportunistic behaviors existing in emerging countries. In this sense, aiming at reducing risk, companies from less economically stable countries aim to disseminate corporate social responsibility in a more explicit way, to seek to reduce uncertainty, and, consequently, to improve their reputation before stakeholders (Matten \& Moon, 2008), as well as their evaluation by rating agencies.

Given the diversity of agencies that issue this data, and to be able to confer comparability, the Moody's ranking was used, which is part of The Big Three group of rating agencies (Fitch Ratings, Moody's, and Standard \& Poor's). These agencies categorize countries into two main initial groups: investment grade and speculative grade. The choice by Moody's is also justified because it holds about $40 \%$ of the global credit rating market, in addition to carrying out this activity for more than 40 years and having a legitimate level of credibility, having overcome major crises without major damage to its reputation (Hill, 2002).

H9: Ceteris paribus, the level of CSR disclosure is negatively influenced by the economic stability of the country (STAB).

\section{RESEARCH METHODS}

Of all the companies on the Global 500 list from Fortune magazine (2019), only companies in the energy sector were selected, resulting in a population of 84 companies in this sector. After selecting the companies, the environmental and financial reports and the reference form of the companies were consulted. And because of data unavailability, 22 companies were excluded, resulting in a sample of 62 companies from 25 countries. Thus, the sample is non-probabilistic and represents $73.81 \%$ of the population.

The international sample consists of 62 leading multinationals in the energy sector distributed in 25 countries: Germany (2), Saudi Arabia (1), Australia (1), Austria (1), Brazil (3), Canada (2), China (4), South Korea (3), Spain (3), United States (12), France (4), Netherlands (1), India (3), Indonesia (1), Italy (2), Japan (4), Malaysia (1), Mexico (2), Norway (1), Poland (1), United Kingdom (4), Russia (3), Switzerland (1), Taiwan (1) and Turkey (1). The sample covers three years of analysis, between 2016 and 2018. The year 2016 was chosen, given that in the 
previous year, in 2015, 193 countries marked the United Nations Global Compact (UN) for the sustainable development of the planet.

The collection process used follows the framework developed by Gamerschlag, Moller and Verbeeten (2010). The authors have a set of keywords that have a strict relationship with corporate social responsibility. Table 1 shows the words used, and from the first word to the $8^{\text {th }}$ focuses on the environmental pillar and the $9^{\text {th }}$ word the $32^{\text {nd }}$ in the social pillar. Thus, the disclosure of corporate social responsibility represents the variable dependent on the study.

\section{Table 1}

Selected words

\begin{tabular}{|c|c|c|c|}
\hline 1. Recycling & 9. Job & $\begin{array}{l}\text { 17. Equal } \\
\text { opportunities }\end{array}$ & 25. Corruption \\
\hline $\begin{array}{l}\text { 2. Energy } \\
\text { consumption }\end{array}$ & 10. Turnover & 18. Human rights & 26. Public policies \\
\hline 3. Biodiversity & $\begin{array}{l}\text { 11. Collective } \\
\text { bargaining }\end{array}$ & 19. Discrimination & 27. Compliance \\
\hline 4. Emissions & $\begin{array}{l}\text { 12. Collective } \\
\text { agreements }\end{array}$ & $\begin{array}{l}\text { 20. Freedom of } \\
\text { association }\end{array}$ & 28. Fines \\
\hline 5. Effluent & $\begin{array}{l}\text { 13. Occupational } \\
\text { health }\end{array}$ & 21. Child labor & 29. Sanctions \\
\hline 6. Waste & 14. Safety at work & 22. Forced labor & $\begin{array}{l}\text { 30. Product } \\
\text { responsibility }\end{array}$ \\
\hline 7. Spills & 15. Training & 23. Compulsory work & 31. Customer health \\
\hline $\begin{array}{l}\text { 8. Environmental } \\
\text { impacts }\end{array}$ & 16. Diversity & 24. Community & 32. Customer security \\
\hline
\end{tabular}

Corporate social responsibility disclosure (CSRd) was defined as a dependent variable, with a subdivision of corporate social responsibility (CSRs) into two components: disclosure for the environmental pillar (CSRe) and disclosure for the social pillar (CSRs). The result of the 32-word value was obtained in three different ways, as shown in Table 2.

\section{Table 2}

Selected dependent variables (dummy)

\begin{tabular}{cc} 
Variable & Calculation method \\
\hline CSRd & $\begin{array}{c}\text { Step 1: the frequency of words relating to corporate social responsibility was } \\
\text { performed in the base report. Step 2: divided by the number of pages in this } \\
\text { report. Step 3: the average of the company in the year is compared, with the } \\
\text { average }(\mu) \text { of the sample in the same year, if equal to or greater than } \mu, 1 \text { is } \\
\text { assigned, if less than } \mu, 0 \text { is assigned. }\end{array}$ \\
\hline CSRe $\quad \begin{array}{c}\text { Step 1: the frequency of words relating to the environmental pillar of the CSR } \\
\text { was performed in the base report. The second step and the 3rd step are } \\
\text { repeated. }\end{array}$ \\
CSRs $\quad \begin{array}{c}\text { Step 1: the frequency of words relating to the social pillar of the CSR was } \\
\text { performed in the base report. The second step and the 3rd step are repeated. }\end{array}$
\end{tabular}


Figure 1 presents the independent control variables, as well as the calculation method and the expected signal of the estimated coefficient. These variables are institutional in nature and were selected to measure the cultural system of the countries analyzed. For each variable of the cultural system, an average was operationalized with the values of the variables of the 62 countries. Thus, if the value of the country variable is below the average, it receives the number 1. For example, if the average indulgence value of all countries gave 61, and the country Brazil has indulgence of 59. Therefore, Brazil is assigned a value of 1 in this variable.

\begin{tabular}{|c|c|c|c|c|}
\hline Variable & Type & Calculation method & Sign & Reference \\
\hline INDG & \multirow{6}{*}{ Dummy. } & \multirow{4}{*}{$\begin{array}{l}\text { If below the sample } \\
\text { mean }=1 \\
\text { If above the sample } \\
\text { mean; }=0\end{array}$} & - & Sun, Yoo, Park, \& Hayati (2019) \\
\hline PWD & & & - & \multirow{5}{*}{$\begin{array}{c}\text { Gamerschlag, Moller e Verbeeten } \\
\text { (2010), Hofstede (1983), García- } \\
\text { Sánchez, Rodríguez-Ariza, \& Frías- } \\
\text { Aceituno (2013), Cabeza-García, } \\
\text { Del Brio, \& Rueda (2019), Cubilla- } \\
\text { Montilla et al. (2019) }\end{array}$} \\
\hline IND & & & - & \\
\hline MSC & & & - & \\
\hline UNAC & & \multirow{2}{*}{$\begin{array}{l}\text { If above the sample } \\
\text { mean = } 1 \\
\text { If below the sample } \\
\text { mean; = } 0\end{array}$} & + & \\
\hline LTOR & & & + & \\
\hline LEGALS & Categorical & $\begin{array}{c}\text { If civil law }=1 ; \\
\text { If common law }=3 \text {; If } \\
\text { mixed }=2 ; \text { If religion = } \\
0\end{array}$ & + & $\begin{array}{c}\text { Kolk \& Perego (2010), Coluccia, } \\
\text { Fontana, \& Solimene (2018), Jensen } \\
\text { \& Berg (2012), Smith, Adhikari, \& } \\
\text { Tondkar (2005). }\end{array}$ \\
\hline CMICS & Dummy & $\begin{array}{l}\text { If high context }=1 \\
\text { If low context }=0\end{array}$ & + & 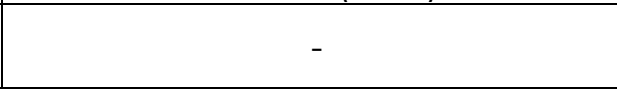 \\
\hline STAB & Categorical & $\begin{array}{l}\text { If the risk index has } \\
\text { been improved = 3; If } \\
\text { stable = 2; if the risk } \\
\text { index worsened }=1\end{array}$ & - & - \\
\hline ROE & \multirow{3}{*}{$\begin{array}{l}\text { Numeric } \\
\text { continues }\end{array}$} & $\begin{array}{c}\text { Net } \\
\text { Income/Shareholder } \\
\text { Equity }\end{array}$ & + & \multirow{3}{*}{$\begin{array}{c}\text { Stjepcevic \& Siksnelyte } \\
\text { (2017), García-Sánchez, Rodríguez- } \\
\text { Ariza, \& Frías-Aceituno } \\
\text { (2013), Cabeza-García, Del Brio, \& } \\
\text { Rueda (2019), Esteban, Villardón, \& } \\
\text { Sánchez (2017). }\end{array}$} \\
\hline LogSize & & $\begin{array}{c}\text { Logarithm in base } 10 \\
\text { of the company's } \\
\text { assets }\end{array}$ & + & \\
\hline ThirdPE & & $\begin{array}{c}(\mathrm{CL}+\mathrm{NCL}) / \text { Shareholder } \\
\text { Equity }\end{array}$ & + & \\
\hline AGE & Categorical & $\begin{array}{l}\text { Age of country: } 1- \\
\begin{array}{c}250=1 ; 251-500=2 \\
>500=3\end{array}\end{array}$ & + & - \\
\hline
\end{tabular}

Figure 1 - Independent and control variables, with due proxies and expected signals Source: Authors.

The study presents eight independent variables: PWD, IND, MSC, UNAC, LTOR, INDG, LEGALS and CMICS. As control variables, five variables were selected, two of categorical type and three numerical type. The numerical control variables were LogSize, ROE and ThirdPE. As categorical control variables, the country age (AGE) and country risk stability (STAB) were selected. For the 
analysis of hypotheses $\mathrm{H} 1$ to $\mathrm{H}$ 9, three econometric models were elaborated, as shown below.

$$
\begin{aligned}
& \operatorname{CSR}_{\mathrm{d}}=\beta_{0}+\beta_{1} P W D_{i t}+\beta_{2} I N D_{i t}+\beta_{3} M S C_{i t}+\beta_{4} U N A C_{i t}+\beta_{5} L T O R_{i t}+\beta_{6} I N D G_{i t} \\
& +\beta_{7} \text { LEGALS }_{i t}+\beta_{8} \text { CMICS }_{i t}+\beta_{9} \text { STAB it }+\beta_{10} \text { ROE }_{i t}+\beta_{11} \text { ThirdPE }_{i t} \\
& +\beta_{12} \text { LogSize }_{\text {it }}+\beta_{13} A G E_{\text {it }}+\varepsilon_{\text {it }} \\
& \operatorname{CSR}_{e}=\beta_{0}+\beta_{1} P W D_{i t}+\beta_{2} I N D_{i t}+\beta_{3} M S C_{i t}+\beta_{4} U N A C_{i t}+\beta_{5} L T O R_{i t}+\beta_{6} I N D G_{i t} \\
& +\beta_{7} \text { LEGALS }_{i t}+\beta_{8} \text { CMICS }_{i t}+\beta_{9} \text { STAB }_{i t}+\beta_{10} \text { ROE }_{i t}+\beta_{11} \text { ThirdPE }_{i t} \\
& +\beta_{12} \operatorname{LogSize}_{\text {it }}+\beta_{13} A G E_{\text {it }}+\varepsilon_{\text {it }} \\
& \operatorname{CSR}_{\mathrm{g}}=\beta_{0}+\beta_{1} P W D_{i t}+\beta_{2} I N D_{i t}+\beta_{3} M C_{i t}+\beta_{4} U N A C_{i t}+\beta_{5} L T O R_{i t}+\beta_{6} I N D G_{i t} \\
& +\beta_{7} \text { LEGALS }_{i t}+\beta_{8} \text { CMICS }_{i t}+\beta_{9} \text { STAB }_{i t}+\beta_{10} \text { ROE }_{i t}+\beta_{11} \text { ThirdPE }_{i t} \\
& +\beta_{12} \operatorname{LogSize}_{\text {it }}+\beta_{13} A G E_{\text {it }}+\varepsilon_{\text {it }}
\end{aligned}
$$

Data analysis and treatment were performed by calculating the proxies, obtaining the mean per individual of the sample for the analyzed period, as well as the median and standard deviation. Excel software ${ }^{\circledR}$ was used for the organization and calculation of proxies, with subsequent use of STATA 13®, for statistical tests. The econometric models tested are nonlinear with panel data by Logit regression because the dependent variable was obtained through a binary response (dummy 1 or 0 ).

\section{RESULTS AND DISCUSSION}

The analysis was initially based on the survey of the characteristics of the institutional context of the analyzed countries, expressed in Table 3. To this end, it was identified that the countries in the sample are located on four distinct continents (region). Most European countries follow the civil law system. Asian countries have a high context communication profile.

In addition, European countries have a lower power distance, greater risk aversion and greater long-term orientation. Asian countries have levels of individualism below the sample average. Countries with below average indulgence rates were in Asia or Europe. The data also reveal that, in the analyzed period, most countries in the sample have an economic stability, that is, they have in the STAB column the value number 0 or the signal + . 
Table 3

Descriptive statistics of independent variables

\begin{tabular}{|c|c|c|c|c|c|c|c|c|c|}
\hline Country/Variable & PWD & IND & MSC & UNAC & LTOR & INDG & LEGALS & CMICS & STAB \\
\hline Australia & 38 & 90 & 61 & 51 & 21 & 71 & $\begin{array}{c}\text { common } \\
\text { law }\end{array}$ & $\begin{array}{c}\text { low } \\
\text { context }\end{array}$ & 0 \\
\hline Austria & 11 & 55 & 79 & 70 & 60 & 63 & civil law & $\begin{array}{c}\text { low } \\
\text { context }\end{array}$ & + \\
\hline Brazil & 69 & 38 & 49 & 76 & 44 & 59 & civil law & $\begin{array}{c}\text { high } \\
\text { context }\end{array}$ & + \\
\hline England & 35 & 89 & 66 & 35 & 51 & 69 & $\begin{array}{c}\text { common } \\
\text { law }\end{array}$ & $\begin{array}{c}\text { low } \\
\text { context }\end{array}$ & + \\
\hline Canada & 39 & 80 & 52 & 48 & 36 & 68 & $\begin{array}{c}\text { common } \\
\text { law }\end{array}$ & $\begin{array}{c}\text { low } \\
\text { context }\end{array}$ & 0 \\
\hline China & 80 & 20 & 66 & 30 & 87 & 24 & civil law & $\begin{array}{c}\text { high } \\
\text { context }\end{array}$ & - \\
\hline France & 68 & 71 & 43 & 86 & 63 & 48 & civil law & $\begin{array}{l}\text { high } \\
\text { context }\end{array}$ & 0 \\
\hline Germany & 35 & 67 & 66 & 65 & 83 & 40 & civil law & $\begin{array}{c}\text { low } \\
\text { context }\end{array}$ & 0 \\
\hline India & 77 & 48 & 56 & 40 & 51 & 26 & $\begin{array}{c}\text { common } \\
\text { law }\end{array}$ & $\begin{array}{l}\text { high } \\
\text { context }\end{array}$ & - \\
\hline Indonesia & 78 & 14 & 46 & 48 & 62 & 38 & civil law & $\begin{array}{l}\text { high } \\
\text { context }\end{array}$ & - \\
\hline Italy & 50 & 76 & 70 & 75 & 61 & 30 & civil law & $\begin{array}{l}\text { high } \\
\text { context }\end{array}$ & + \\
\hline Japan & 54 & 46 & 95 & 92 & 88 & 42 & civil law & $\begin{array}{l}\text { high } \\
\text { context }\end{array}$ & 0 \\
\hline Malaysia & 100 & 26 & 50 & 36 & 41 & 57 & misto & $\begin{array}{l}\text { high } \\
\text { context }\end{array}$ & 0 \\
\hline Mexico & 81 & 30 & 69 & 82 & 24 & 97 & civil law & $\begin{array}{l}\text { high } \\
\text { context }\end{array}$ & 0 \\
\hline Netherlands & 38 & 80 & 14 & 53 & 67 & 68 & civil law & $\begin{array}{c}\text { low } \\
\text { context }\end{array}$ & 0 \\
\hline Norway & 31 & 69 & 8 & 50 & 35 & 55 & civil law & $\begin{array}{c}\text { low } \\
\text { context }\end{array}$ & 0 \\
\hline Poland & 68 & 60 & 64 & 93 & 38 & 29 & civil law & $\begin{array}{c}\text { low } \\
\text { context }\end{array}$ & 0 \\
\hline Russia & 93 & 39 & 36 & 95 & 81 & 20 & civil law & $\begin{array}{l}\text { high } \\
\text { context }\end{array}$ & - \\
\hline Saudi Arabia & 95 & 25 & 60 & 80 & 36 & 52 & religion & $\begin{array}{l}\text { high } \\
\text { context }\end{array}$ & + \\
\hline South Korea & 60 & 18 & 39 & 85 & 100 & 29 & civil law & $\begin{array}{l}\text { high } \\
\text { context }\end{array}$ & 0 \\
\hline Spain & 57 & 51 & 42 & 86 & 48 & 44 & civil law & $\begin{array}{l}\text { high } \\
\text { context }\end{array}$ & - \\
\hline Switzerland & 34 & 68 & 70 & 58 & 74 & 66 & civil law & $\begin{array}{c}\text { low } \\
\text { context }\end{array}$ & 0 \\
\hline Taiwan & 58 & 17 & 45 & 69 & 93 & 49 & civil law & $\begin{array}{l}\text { high } \\
\text { context }\end{array}$ & 0 \\
\hline Turkey & 66 & 37 & 45 & 85 & 46 & 49 & civil law & $\begin{array}{l}\text { high } \\
\text { context }\end{array}$ & + \\
\hline United States & 40 & 91 & 62 & 46 & 26 & 68 & $\begin{array}{c}\text { common } \\
\text { law }\end{array}$ & $\begin{array}{c}\text { low } \\
\text { context }\end{array}$ & 0 \\
\hline
\end{tabular}

Caption + = countries with improved economic stability between 2016 and 2018, according to Moody's; 0 = with the same level of stability; - = with worsening stability economy.

Source: Authors. 
According to Table 4, the descriptive statistics of the data indicate that the dominant profile is of companies in contexts of lower power distance, greater individualism and greater masculinity, lower risk aversion, greater orientation to long-term commitment, lower indulgences, greater economic stability. In addition, it was possible to observe that most countries follow the civil law system, have a high context communication profile and have up to 250 years, since the constituent normative.

Table 4

Descriptive statistics of independent variables

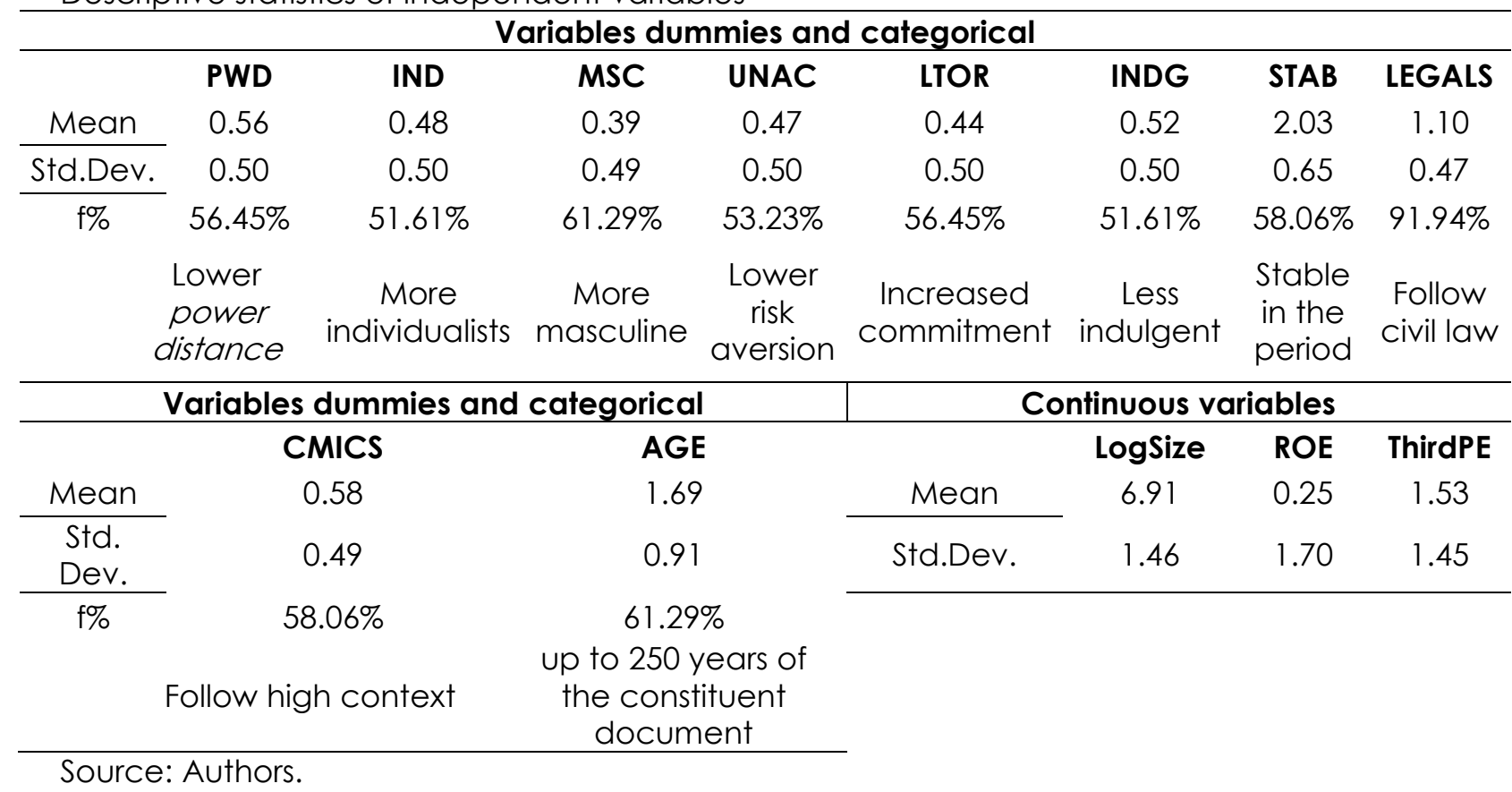

As for the tests, the three models did not present multilinearity problems, since no VIF value was greater than 10. The correlation matrix showed no strong correlation. In other words, $86.98 \%$ of the correlations of the independent variables of the study are considered weak correlations. Table 5 shows the correlation matrix of the variables analyzed. 
Table 5

Correlation matrix (independent variables)

\begin{tabular}{|c|c|c|c|c|c|c|c|c|c|c|c|c|c|}
\hline & 1 & 2 & 3 & 4 & 5 & 6 & 7 & 8 & 9 & 10 & 11 & 12 & 13 \\
\hline 1. PWD & 1 & & & & & & & & & & & & \\
\hline 2. IND & 0.05 & 1.00 & & & & & & & & & & & \\
\hline 3. MSC & $\begin{array}{c}0.43 \\
-\end{array}$ & 0.04 & $\begin{array}{c}1.00 \\
-\end{array}$ & & & & & & & & & & \\
\hline 4. UNAC & 0.44 & 0.03 & 0.42 & 1.00 & & & & & & & & & \\
\hline 5. LTOR & $\begin{array}{c}0.27 \\
-\end{array}$ & 0.08 & $\begin{array}{c}0.15 \\
-\end{array}$ & 0.24 & $\begin{array}{c}1.00 \\
-\end{array}$ & & & & & & & & \\
\hline 6. INDG & $\begin{array}{c}0.27 \\
-\end{array}$ & $\begin{array}{c}0.17 \\
-\end{array}$ & $\begin{array}{c}0.14 \\
-\end{array}$ & 0.20 & $\begin{array}{c}0.65 \\
-\end{array}$ & $\begin{array}{c}1.00 \\
-\end{array}$ & & & & & & & \\
\hline 7. STAB & 0.28 & 0.33 & $\begin{array}{c}0.21 \\
-\end{array}$ & 0.37 & 0.03 & 0.23 & $\begin{array}{c}1.00 \\
-\end{array}$ & & & & & & \\
\hline 8.LEGALS & 0.27 & $\begin{array}{c}0.07 \\
-\end{array}$ & 0.43 & $\begin{array}{c}0.19 \\
-\end{array}$ & 0.02 & $\begin{array}{c}0.11 \\
-\end{array}$ & $\begin{array}{c}0.24 \\
-\end{array}$ & $\begin{array}{c}1.00 \\
-\end{array}$ & & & & & \\
\hline 9. CMICS & $\begin{array}{c}0.56 \\
-\end{array}$ & 0.58 & $\begin{array}{c}0.10 \\
-\end{array}$ & $\begin{array}{c}0.57 \\
-\end{array}$ & $\begin{array}{c}0.23 \\
-\end{array}$ & 0.49 & 0.06 & 0.01 & $\begin{array}{c}1.00 \\
-\end{array}$ & & & & \\
\hline 10. AGE & $\begin{array}{c}0.40 \\
-\end{array}$ & 0.12 & 0.04 & $\begin{array}{c}0.01 \\
-\end{array}$ & $\begin{array}{c}0.24 \\
-\end{array}$ & 0.08 & 0.15 & $\begin{array}{c}0.14 \\
-\end{array}$ & $\begin{array}{c}0.21 \\
-\end{array}$ & $\begin{array}{c}1.00 \\
-\end{array}$ & & & \\
\hline 11.LogSize & $\begin{array}{c}0.21 \\
-\end{array}$ & 0.14 & 0.10 & 0.05 & 0.21 & $\begin{array}{c}0.29 \\
-\end{array}$ & 0.18 & $\begin{array}{c}0.55 \\
-\end{array}$ & $\begin{array}{c}0.37 \\
-\end{array}$ & 0.11 & 1.00 & & \\
\hline 12. ROE & 0.06 & 0.01 & 0.01 & $\begin{array}{c}0.10 \\
-\end{array}$ & 0.05 & $\begin{array}{c}0.05 \\
-\end{array}$ & $\begin{array}{c}0.03 \\
-\end{array}$ & 0.02 & 0.08 & $\begin{array}{c}0.03 \\
-\end{array}$ & $\begin{array}{c}0.02 \\
-\end{array}$ & $\begin{array}{c}1.00 \\
-\end{array}$ & \\
\hline 13.ThirdPE & 0.01 & 0.09 & 0.07 & 0.10 & 0.05 & 0.17 & 0.10 & 0.06 & 0.03 & 0.04 & 0.14 & 0.02 & 1.00 \\
\hline
\end{tabular}

Source: Authors.

In order to test normality, the Shapiro Wilk test was applied, which indicated that the Logit model is appropriate, since the values of the variables did not present normal distribution. This test presented p-value of 0.00 . In addition, the study-dependent variable is of the binary type, i.e. zero or one. Initially, the Hausman Test was performed, where the choice of the model with random effects was verified. It is noteworthy that the Wooldridge test rejected the hypothesis of autocorrelation and the Wald test did not confirm the absence of heteroscedasticity in the models.

Table 6 presents the results of the variables of each model that were significant, as well as the comparison of the signal found with the expected signal. The values that did not give significant were omitted from the analysis. It is highlighted that model 2 (CSRe) representing the environmental pillar did not present any significant variable, not even $10 \%$. 
Table 6

Results of the models, significant variables and relationship found

\begin{tabular}{|c|c|c|c|c|c|c|c|}
\hline \multicolumn{8}{|c|}{ Model 1 - CSRd } \\
\hline $\begin{array}{c}\text { Num } \\
\text { of } \\
\text { obs. }\end{array}$ & $\begin{array}{l}\text { Test } \\
\text { LR }\end{array}$ & $\begin{array}{l}\text { Indep. } \\
\text { Var. }\end{array}$ & $\begin{array}{l}\text { Odds } \\
\text { ratio }\end{array}$ & $\beta$ & P-value & $\begin{array}{l}\text { Expected } \\
\text { Signal }\end{array}$ & Signal Found \\
\hline & & PWD & 16.26 & 2.78 & $0.076^{* * *}$ & - & + \\
\hline 186 & 33.08 & LTOR & 14.71 & 2.68 & $0.091^{* * *}$ & + & + \\
\hline & & INDG & 0.02 & -3.54 & $0.081^{* * *}$ & - & - \\
\hline \multicolumn{8}{|c|}{ Model 3 - CSRs } \\
\hline \multirow[t]{2}{*}{$\begin{array}{l}\text { Num } \\
\text { of } \\
\text { obs. }\end{array}$} & $\begin{array}{l}\text { Test } \\
\text { LR }\end{array}$ & $\begin{array}{l}\text { Indep. } \\
\text { Var. }\end{array}$ & $\begin{array}{l}\text { Odds } \\
\text { ratio }\end{array}$ & $\beta$ & P-value & $\begin{array}{l}\text { Expected } \\
\text { Signal }\end{array}$ & Signal Found \\
\hline & & PWD & 19.47 & 2.96 & $0.01^{* *}$ & - & + \\
\hline \multirow[t]{2}{*}{186} & 15.67 & MSC & 5.35 & 1.67 & $0.07^{* * *}$ & - & + \\
\hline & & STAB & 0.22 & -1.49 & $0.01^{* *}$ & - & - \\
\hline
\end{tabular}

Table 7 presents the results for panel data regression for model 1 and model 3. Model 1 (CSRd) is the total CSR, while model 3 (CSRS) is the social pillar of CSR. For model 1 , the data show that the distance to power and the long-term orientation of the country positively affect the disclosure of corporate social responsibility. On the other hand, indulgences negatively affect social and environmental disclosure. In relation to model 3 , it was found that distance to power and masculinity positively affect the dissemination of social information in the reports, while the stability of the country negatively influences this disclosure.

The results suggest that in countries with a great distance to power, energy companies disseminate more socio-environmental information. That is, in societies where people accept and expect power to be distributed unequally, companies carry out social and environmental dissemination in more detail. Thus, in more hierarchical and unequal countries, such as Brazil and Indonesia, multinationals in the energy sector try to improve their reputation, presenting greater socioenvironmental transparency. Being transparent can favor new foreign investments for business expansion since the internal institutional environment is unfavorable. These findings contradict the results of Garcia-Sanchez, CuadradoBallesteros e Frias-Aceituno (2016). However, García-Sánchez, Rodríguez-Ariza e Frías-Aceituno (2013) also found a positive impact between distance to power and social and environmental dissemination.

Analyzing the odds ratio of the PWD variable, it is time that the chance of a company in a lower power distance cultural environment performing total CSR is $1526 \%$ higher than the chance of a company inserted within a high power distance environment, and this value is even higher when it comes to CSR of the social pillar (1847\%).

The more a country is oriented towards the long term, the more its companies carry out social and environmental disclosure. In view of this, countries that encourage the economy and efforts in modern education to prepare for the future have companies that better inform their environmental actions. Thus, Asian countries such as Japan and South Korea, firms tend to disclose not only financial reports to inform shareholders, but also tend to 
disseminate environmental reports to meet the demands of primary and secondary stakeholders. The results confirm the previous findings of GarciaSanchez, Cuadrado-Ballesteros and Frias-Aceituno (2016).

The odds ratio of the LTOR variable follows the logic of what happened with the PWD variable, that is, the chance of a company in a cultural environment of guidance for the long-term performing total CSR is $1371 \%$ higher than the chance of a company inserted within an environment with orientation for the short term (more immediate).

Companies with the headquarters located in more indulgent countries disclose more information about their social and environmental practices. More indulgent countries are characterized by a society that allows more bonuses related to human desires, such as enjoying more free time. Thus, in more indulgent countries, such as the United States, energy firms tend to release an environmental report with less information than in less indulgent countries, such as Spain. The results are in accordance with the findings of Sun, Yoo, Park and Hayati (2019). The authors claim that more indulgent countries, such as the United States and England, firms are focused on meeting the demands of investors and shareholders.

In the INDG variable, the odds ratio is less than 1, indicating a lower chance of occurrence of the company event inserted in a context of lower indulgence to present total CSR. Thus, the chance of a company in an indulgent cultural environment performing total CSR is $98 \%$ lower than the chance of a nonindulgent country performing total CSR, a negative relationship, according to the B coefficient.

The data show that there is a positive effect of the level of masculinity of the country and the social dissemination of companies. At first, it was expected that more feminine cultures could report more social information, since in these environments there is more compassion for social causes. However, the results show that in societies focused on ambition and competitiveness, firms tend to disseminate environmental reports with more quality in social information. Thus, companies within Japanese and Italian cultures tend to report more their social actions than companies located in the Netherlands and Norway. Oliveira, Rodrigues Júnior, de Oliveira Lima e de Freitas (2018) they also found a negative relationship between more feminine cultures and socio-environmental dissemination in 2015 in Latin America.

In the MSC variable, the odds ratio is greater than 1, so the chance of a company in a less masculine (more female) cultural environment performing CSR in the social pillar is $435 \%$ higher than the chance of a more masculine country performing CSR in the social pillar, a positive relationship, according to the $B$ coefficient.

In addition, companies located in economically more stable countries disclose less information than economically fewer stable countries. In other words, in countries with a riskier macroeconomic environment for investments, companies release more social information in their annual reports. Thus, unlike stable economic and institutional environments such as Australia, France, Germany and Switzerland, Brazilian, Indian, and Russian companies try to legitimize themselves through explicit social dissemination. The findings are 
supported by Matten \& Moon (2008). They claim that more marketable environments, firms perform more explicit CSR practices.

In the social pillar of CSR, the variable STAB presented an odds ratio lower than 1, and a negative sign for the coefficient, indicating that the chance of a company performing CSR in the social pillar when inserted in a more stable economic environment is $78 \%$ lower than the chance of a company inserted in a less stable economic environment. This finding suggests that companies in environments with greater economic stability do not need to legitimize their CSR actions in the same proportion as companies located in more volatile economic environments. Thus, companies in marketable environments seek through the dissemination of CSR a greater legitimation of their actions and reduction of uncertainties.

To verify the consistency of the results obtained, the three models were analyzed by grouping the countries into continents. This grouping was performed through logit regression. The results for the models are presented in Table 7.

Table 7

Logit regression for grouping countries

\begin{tabular}{|c|c|c|c|c|c|c|}
\hline \multicolumn{7}{|c|}{ Model 1 - CSRd } \\
\hline $\begin{array}{l}\text { Num of } \\
\text { obs. }\end{array}$ & $R^{2}$ adjusted & Variables & $\beta$ & P-value & $\begin{array}{l}\text { Expected } \\
\text { Signal }\end{array}$ & Signal Found \\
\hline \multirow{5}{*}{79} & & IND & 2.46 & 0.00 & - & + \\
\hline & & INDG & 2.40 & 0.015 & - & + \\
\hline & 0.54 & STAB & 0.33 & 0.00 & - & + \\
\hline & & LEGALS & 1.65 & 0.00 & + & + \\
\hline & & CMICS & 0.46 & 0.06 & + & + \\
\hline \multicolumn{7}{|c|}{ Model 2 - CSRe } \\
\hline $\begin{array}{l}\text { Num of } \\
\text { obs. }\end{array}$ & $R^{2}$ adjusted & Variables & $\beta$ & P-value & $\begin{array}{l}\text { Expected } \\
\text { Signal }\end{array}$ & Signal Found \\
\hline \multirow{6}{*}{76} & \multirow{6}{*}{0.51} & IND & 2.49 & 0.00 & - & + \\
\hline & & INDG & 3.31 & 0.00 & - & + \\
\hline & & LTOR & 0.39 & 0.00 & + & + \\
\hline & & STAB & 0.46 & 0.00 & - & + \\
\hline & & LEGALS & 1.34 & 0.05 & + & + \\
\hline & & AGE & 1.24 & 0.03 & $+/-$ & + \\
\hline \multicolumn{7}{|c|}{ Model 3-CSRs } \\
\hline $\begin{array}{l}\text { Num of } \\
\text { obs. }\end{array}$ & $R^{2}$ adjusted & Variables & $\beta$ & P-value & $\begin{array}{l}\text { Expected } \\
\text { Signal }\end{array}$ & Signal Found \\
\hline \multirow{6}{*}{74} & \multirow{6}{*}{0.48} & IND & 2.26 & 0.00 & - & + \\
\hline & & LTOR & 0.61 & 0.04 & + & + \\
\hline & & INDG & 3.57 & 0.00 & - & + \\
\hline & & STAB & 0.37 & 0.00 & - & + \\
\hline & & LEGALS & 2.08 & 0.00 & + & + \\
\hline & & CMICS & 0.34 & 0.02 & + & + \\
\hline
\end{tabular}

Note: *: Significant to 1\%; **: significant to $2 \%$; : significant to $10 \%$

Source: Authors.

The results suggest that in more individualistic cultures, companies tend to disseminate more socio-environmental information. These findings differ from Garcia-Sanchez, Cuadrado-Ballesteros and Frias-Aceituno (2016). In the three models, the relationship found was positive, contradicting the hypothesis that collective cultures disseminate CSR actions with higher quality. Thus, firms from more individualistic countries tend to show their concern about social and 
environmental causes with more information in the reports than more collectivist countries. More individualistic societies, such as England, focus on the "I." Thus, managers of these cultures within an organizational environment can transfer the "individual-l" to the "corporation-l" and play a fundamental role in raising the corporate image through social and environmental reports.

Companies located in countries that follow the civil law legal system disclose more socio-environmental information. From this perspective, evidence shows that countries with a civil law system adopt more laws that benefit employees and protect other stakeholders (Gallego-Álvarez \& Pucheta-Martínez, 2020). Companies in these countries, as predicted by the hypothesis, disclose more CSR information than companies from countries that follow common law. Thus, government intervention in economic activity may favor the more responsible performance of companies in favor of sustainability. The results are in accordance with the findings of Garcia-Sanchez et al. (2016), Jensen e Berg (2012) e Miniaoui, Chibani, e Hussainey (2019).

In addition, the data reveal that companies located in countries with a high context communication system, such as Brazil, France, India, Italy, and Spain tend to disclose more CSR information than companies from countries with a low context communication system, such as Germany, Australia, Canada, England, Norway, and the United States. Thus, the results show that a country's communication system can positively influence business decisions about CSR. In high context environments, companies release more complete environmental reports using multiple sources of information. On the other hand, in low context environments, companies disseminate more direct environmental reports, focusing on rational and explicit information.

For the control variable age of the country, it was found that there is a positive relationship between age and socio-environmental dissemination by companies. Firms located in older countries, which are generally more economically developed than newer ones, are more concerned with CSR practices. In general, older countries have a higher level of development and a more competitive market. Thus, it is expected that in these countries, companies will disclose more CSR information to meet society's demands and build an additional corporate image.

When grouped in countries, the results show that the variable indulgence has a positive effect in relation to the dissemination of CSR. This means that in countries with fewer restrictions on the human desire to seize time, companies are committed to making more transparent disclosure. For the variable that measures the long-term orientation of countries, it was found that the more a country has a future-oriented culture, firms publish more socio-environmental information in their reports. Finally, for the grouping of countries, the results showed that there is a positive relationship between the country's economic stability and the dissemination. In countries with greater economic stability, companies tend to find it easier to finance. Thus, as they have more resources, they can invest in the preparation of a more detailed environmental report. In countries with instability, companies tend to act more on their short-term survival. 


\section{CONCLUSION AND IMPLICATIONS}

The aim of this paper was to examine the effect of the cultural system on the disclosure of corporate social responsibility of companies in the energy sector, which can be considered achieved. Thus, the level of CSR disclosure was examined for an international sample of 62 energy companies listed in Fortune magazine (2019). The cultural system was composed by culture variables of the Hofstede (1983), variable of the country's legal system (civil law, common law, mixed and religion) and variable of the communication system (high context or low context).

Regarding the $\mathrm{H} 1$ hypothesis, it was found that the level of CSR disclosure is positively influenced by the distance to the power of the country, contrary to $\mathrm{Hl}$. For hypothesis $\mathrm{H} 2$, the data showed that the level of disclosure of CSR is positively influenced by the individualism of the country, diverging from the forecast for $\mathrm{H} 2$. Regarding the $\mathrm{H} 3$ hypothesis, it was found that the level of disclosure of social information is positively influenced by the country's masculinity. Thus, $\mathrm{H} 3$ has not been confirmed. The values found for the $\mathrm{H} 4$ hypothesis did not present a significant $p$-value. However, the negative influence of the country's aversion to uncertainty on the dissemination of CSR was not confirmed.

Furthermore, the data showed that the level of CSR disclosure is positively influenced by the country's long-term orientation, confirming the $\mathrm{H} 5$ hypothesis. For hypothesis $\mathrm{H} 6$, it was evidenced that there is a positive relationship between the level of CSR disclosure and lower levels of indulgences in the country, confirming H6. The H7 hypothesis was confirmed, since it was found that the level of disclosure of CSR is positively influenced by the civil law system. Socioenvironmental disclosure is positively affected by the high context communication system, confirmed by the H8 hypothesis. Finally, the study confirmed hypothesis $\mathrm{H}$, showing that the level of disclosure of CSR is negatively influenced by the economic stability of the country.

The results obtained allow us to conclude that the cultural system of the countries can affect the reporting of corporate social responsibility in companies in the energy sector, thus answering the research question presented, with the due reservation that each of the factors of the cultural system exert influences in different signal and forces. Therefore, cultural issues and institutional differences contribute to companies to have more CSR practices. In addition, it is perceived that in countries with similar cultural systems, firms also have a similar level of socio-environmental dissemination. Therefore, the cultural, legal and communication dimension plays an important role in the behavior of firms. Consequently, cultural differences between countries result in different stakeholder pressures for corporate social responsibility information.

These findings contribute academically to institutional theory, bringing new empirical evidence that the environment in which the firm is inserted can affect its socio-environmental actions. In addition, this research tested for the first time in studies on CSR the following variables: country age, country stability and country communication system. This made it possible to bring new directions to studies that work with explanatory factors for the dissemination of CSR. In addition, the article can test and prove the statistical effect of the cultural variable indulgences, a variable still little used in previous studies about CSR reporting. 
Through these academic contributions, this study also has managerial and governmental implications. Companies wishing to start operations in other countries should investigate how the country's cultural system behaves, because the decision-making process should be different, depending on the country's development context. Environmental practices that have been given right in certain institutional environments may not be adequate in others due to the existence of different cultural systems. In addition, governments can incorporate into their agendas the discussion of laws that favor increased business transparency over CSR practices to contribute to the sustainable development of the planet.

For future research, some limitations of this study should be overcome. This study used only 25 countries. The inclusion of new countries can give greater robustness to the results, modifying them. Thus, due to these limitations, the results should be interpreted considering their methodological limitations in relation to the sample. Future studies should verify the results obtained, considering other variables to represent the cultural system. Finally, it is suggested the inclusion of other sectors in the sample, which can be analyzed in a grouped way, which can generate comparative results sector by sector.

\section{REFERENCES}

Abugre, J. B., \& Anlesinya, A. (2020). Corporate social responsibility strategy and economic business value of multinational companies in emerging economies: The mediating role of corporate reputation. Business Strategy and Development, 3(1), 4-15. DOl: 10.1002/bsd2.70

Aboagye-Otchere, F. K., Simpson, S. N. Y., \& Kusi, J. A. (2019). The influence of environmental performance on environmental disclosures: An empirical study in Ghana. Business Strategy \& Development, 3(1), 98-

111. DOI:10.1002/bsd2.81

Branco, M. C., \& Rodrigues, L. L. (2006). Communication of corporate social responsibility by Portuguese banks. Corporate Communications: An International Journal, $17(3), 232-248$. DOI: 10.1108/13563280610680821

Cabeza-García, L., Del Brio, E. B., \& Rueda, C. (2019). Legal and cultural factors as catalysts for promoting women in the boardroom. BRQ Business Research Quarterly, 22(1), 56-67. DOI: 10.1016/j.brq.2018.06.004

Carroll, A. B. (1979). A Three-Dimensional Conceptual Model of Corporate Performance. The Academy of Management Review, 4(4), 497. DOI: $\underline{10.2307 / 257850}$

Clarkson, M.B. (1995) A stakeholder framework for analyzing and evaluating corporate social performance. Academy of Management Review, 20, 92117. DOI: $\underline{10.2307 / 258888}$ 
Coluccia, D., Fontana, S., \& Solimene, S. (2018). Does institutional context affect CSR disclosure? A study on Eurostoxx 50. Sustainability (Switzerland), 10(8). DOI: $10.3390 /$ sul0082823

Cubilla-Montilla, M., Nieto-Librero, A. B., Galindo-Villardón, M. P., Vicente Galindo, M. P., \& Garcia-Sanchez, I. M. (2019). Are cultural values sufficient to improve stakeholder engagement human and labour rights issues? Corporate Social Responsibility and Environmental Management, 26(4), 938-955. DOI: doi.org/10.1002/csr.1733

De Mooij, M., \& Hofstede, G. (2010). The hofstede model: Applications to global branding and advertising strategy and research. International Journal of Advertising, 29(1), 85-1 10. DOI: 10.2501/S026504870920104X

Esteban, V. A., Villardón, M. P. G., \& Sánchez, I. M. G. (2017). Cultural values on CSR patterns and evolution: A study from the biplot representation. Ecological Indicators, 81, 18-29. DOI: 10.1016/i.ecolind.2017.05.051

Ferri, L. M. (2017). The influence of the institutional context on sustainability reporting. A cross-national analysis. Social Responsibility Journal, 13(1), 24-47. DOI: $10.1108 /$ SRJ-11-2015-0172

Fortune (2019). Global 500 list. Available in: https://fortune.com/global500/2019/search/ Accessed on December 16, 2021.

Freedman, M., \& Jaggi, B. (2009). Global warming and corporate disclosures: A comparative analysis of companies from the European Union, Japan and Canada, Freedman, M. and Jaggi, B. (Ed.) Sustainability, Environmental Performance and Disclosures (Advances in Environmental Accounting \& Management, Vol. 4), Emerald Group Publishing. 129-160.

Freeman, R.E. (1984) Strategic Management: A Stakeholder Approach. Boston: Pitman.

Frias-Aceituno, J. V., Rodriguez-Ariza, L., \& Garcia-Sanchez, I. (2012). The Role of the Board in the Dissemination of Integrated Corporate Social Reporting. Corporate Social Responsibility and Environmental Management, 20(4), 219233. DOI: doi.org/10.1002/csr.1294

Friedman M. (2007) The Social Responsibility of Business Is to Increase Its Profits. In: Zimmerli W.C., Holzinger M., Richter K. (eds) Corporate Ethics and Corporate Governance. Springer, Berlin, Heidelberg.

Gallén, M. L., \& Peraita, C. (2017). The Relationship between Femininity and Sustainability Reporting. Corporate Social Responsibility and Environmental Management, 24(6), 496-508. DOI: doi.org/10.1002/csr.1423 
Gamerschlag, R., Möller, K., \& Verbeeten, F. (2010). Determinants of voluntary CSR disclosure: empirical evidence from Germany. Review of Managerial Science, 5(2-3), 233-262. DOI: 10.1007/s1 1846-010-0052-3

Garcia-Sanchez, I. M., Cuadrado-Ballesteros, B., \& Frias-Aceituno, J. V. (2016). Impact of the Institutional Macro Context on the Voluntary Disclosure of CSR Information. Long Range Planning, 49(1), 15-35. DOI: 10.1016/j.Irp.2015.02.004

García-Sánchez, I.-M., Rodríguez-Ariza, L., \& Frías-Aceituno, J.V. (2013). The cultural system and integrated reporting. International Business Review, 22(5), 828-838. DOI: 10.1016/j.ibusrev.2013.01.007

Gray, R., Owen, D. \& Adams, C. (1996), Accounting and Accountability: Changes and Challengesin Corporate Social and Environmental Reporting, Prentice Hall Europe, Hemel Hempstead.

Hall, E. T. (1992). An Anthropology of Everyday Life. New York: Doubleday/Anchor Books.

Hall, E.T. (1959). The Silent Language. New York: Doubleday; translated to Japanese in 1966 by Masao Kunihiro, Yoshimi Nagai and Mitsuko Saito as Chinmoku No Kotoba. Tokyo: Nanundo.

Helmig, B., Spraul, K., \& Ingenhoff, D. (2013). Under Positive Pressure: How Stakeholder Pressure Affects Corporate Social Responsibility Implementation. Business \& Society, 55(2), 151-187. DOI: $10.1177 / 0007650313477841$

Hill, C. A. (2002). Rating Agencies Behaving Badly: The Case of Enron. Connecticut Law Review, 35, 1145.

Hofstede, G. (2011). Dimensionalizing Cultures: The Hofstede Model in Context. Online Readings in Psychology and Culture, 2(1), 1-26. DOI: 10.9707/2307$\underline{0919.1014}$

Hofstede, G. (1983). National Cultures in Four Dimensions: A Research-Based Theory of Cultural Differences among Nations. International Studies of Management \& Organization, 13(1-2), 46-74.

Jamali, D., Safieddine, A. M., \& Rabbath, M. (2008). Corporate Governance and Corporate Social Responsibility Synergies and Interrelationships. Corporate Governance: An International Review, 16(5), 443-459. DOI: 10.1111/j.1467$\underline{\text { 8683.2008.00702.x }}$

Jensen, J. C., \& Berg, N. (2012). Determinants of Traditional Sustainability Reporting Versus Integrated Reporting. An Institutionalist Approach. Business Strategy and the Environment, 21(5), 299-316. DOI: 10.1002/bse.740

Jensen, M. C. (2001). Value Maximization, Stakeholder Theory, and The Corporate Objective Function. Journal of Applied Corporate Finance, 14(3), 8-21. DOI: $10.2307 / 3857812$ 
Kolk, A., \& Perego, P. (2010). Determinants of the adoption of sustainability assurance statements: An international investigation. Business Strategy and the Environment, 19(3), 182-198. DOI: 10.1002/bse.643

La Porta, R., Lopez-de-Silanes, F., Shleifer, A., \& Vishny, R. W. (1998). Law and Finance. Journal of Political Economy, 106(6), 1113-1155. DOI: 10.1086/250042

Li, Y., Gong, M., Zhang, X. Y., \& Koh, L. (2018). The impact of environmental, social, and governance disclosure on firm value: The role of CEO power. British Accounting Review, 50 11), 60-75. DOI: 10.1016/i.bar.2017.09.007

Lock, I., \& Seele, P. (2013). Analyzing Sector-Specific CSR Reporting: Social and Environmental Disclosure to Investors in the Chemicals and Banking and Insurance Industry. Corporate Social Responsibility and Environmental Management, 22(2), 113-128. DOI: 10.1002/csr.1338

Matten, D., \& Moon, J. (2008). "Implicit" and "Explicit" CSR: A Conceptual Framework for a Comparative Understanding of Corporate Social Responsibility. Academy of Management Review, 33(2), 404-424. DOI: 10.5465/amr.2008.31193458

Michelon, G., Pilonato, S., \& Ricceri, F. (2015). CSR reporting practices and the quality of disclosure: An empirical analysis. Critical Perspectives on Accounting, 33, 59-78. DOI: 10.1016/i.cpa.2014.10.003

Miniaoui, Z., Chibani, F., \& Hussainey, K. (2019). The impact of country-level institutional differences on corporate social responsibility disclosure engagement. Corporate Social Responsibility and Environmental Management, 26(6), 1-14. DOI: 10.1002/csr.1748

Mohamed Adnan, S., Hay, D., \& Van Staden, C. J. (2018). The influence of culture and corporate governance on corporate social responsibility disclosure: A cross country analysis. Journal of Cleaner Production, 198, 820-832. DOI: j.jclepro.2018.07.057

Oliveira, M., Rodrigues Júnior, M., de Oliveira Lima, S., \& de Freitas, G. (2018). The Influence of the Characteristics of the National Business System in the Disclosure of Gender-Related Corporate Social Responsibility Practices. Administrative Sciences, 8(2), 14. DOI: 10.3390/admsci8020014

Othman, H. Ben, \& Zeghal, D. (2006). A study of earnings-management motives in the Anglo-American and Euro-Continental accounting models: The Canadian and French cases. International Journal of Accounting, 41(4), 406435. DOI: j.intacc.2006.09.004

Pinheiro, A.B., Batistella, A., Cavalcante das Chagas, A., \& Haddad Carraro, W. (2020). Relations between institutional environment and level of social disclosure in the banking sector: evidence from Latin America. Revista de Gestão e Secretariado, 17(3), 158-184. DOI: https://doi.org/10.7769/gesec.v11i3.1113 
Pinheiro, A.B., Costa, G.M., \& Sampaio, T.S.L. (2021). Multinacionais em mercados emergentes: Existem pressões institucionais para o Desenvolvimento Sustentável? Revista Brasileira de Administração Científica, 12(2), 347-362 DOI: CBPC2179-684X.2021.002.0028

Pinheiro, A.B., Silva Filho, J.C.L., \& Moreira, M.Z. (2021). Institutional drivers for corporate social responsibility in the utilities sector. Revista de Gestão USP, 28(3), 186-204. DOI: https://doi.org/10.1108/REGE-08-2019-0088

Reimann, M. \& Zimmermann, R. (2019). The Oxford Handbook of Comparative Law. United Kingdom: Oxford University Press.

Roberts, R. W. (1992). Determinants of corporate social responsibility disclosure: An application of stakeholder theory. Accounting, Organizations and Society, 17(6), 595-612. DOI: 10.1016/0361-3682(92)90015-K

Sarkis, J., Gonzalez-Torre, P., \& Adenso-Diaz, B. (2010). Stakeholder pressure and the adoption of environmental practices: The mediating effect of training. Journal of Operations Management, 28(2), 163-176. DOI: j.jom.2009.10.001

Scholtens, B., \& Dam, L. (2007). Cultural values and international differences in business ethics. Journal of Business Ethics, 75(3), 273-284. DOI: 10.1007/s 10551$\underline{006-9252-9}$

Smith, J., Adhikari, A., \& Tondkar, R. H. (2005). Exploring differences in social disclosures internationally: A stakeholder perspective. Journal of Accounting and Public Policy, 24(2), 123-151. DOI: j.jaccpubpol.2004.12.007

Soares, R. A., Abreu, M. C. S. de, Marino, P. de B. L. P., \& Rebouças, S. M. D. P. (2018). Avaliação hierárquica da influência do país, setor e empresa na evidenciação da responsabilidade social corporativa. Contabilidade Vista \& Revista, 29(2), 96-121. DOI: https://doi.org/10.22561/cvr.v29i2.4086

Soares, R. A., Pinheiro, A. B., Abreu, M. C. S. de, \& Marino, P. de B. L. P. (2018). Efeito do Sistema Financeiro na Evidenciação Socioambiental de Empresas em Países Emergentes e Desenvolvidos. Enfoque: Reflexão Contábil, 37(2), 21-35. DOI:10.4025/enfoque.v37i2.34035

Sorrells, K. (1998). "Gifts of Wisdom: An Interview with Dr. Edward T. Hall." The Edge: The E-Journal of Intercultural Relations, 1(3), 1-12.

Stjepcevic, J., \& Siksnelyte, I. (2017). Corporate social responsibility in energy sector. Transformations in Business and Economics, 16(1), 21-33.

Sun, J., Yoo, S., Park, J., \& Hayati, B. (2019). Indulgence versus Restraint: The Moderating Role of Cultural Differences on the Relationship between Corporate Social Performance and Corporate Financial Performance. Journal of Global Marketing, 32(2), 83-92. DOI: $\underline{10.1080 / 08911762.2018 .1464236}$ 
Usman, A. B., \& Amran, N. A. B. (2015). Corporate social responsibility practice and corporate financial performance: evidence from Nigeria companies. Social Responsibility Journal, 17(4), 749-763. DOI: 10.1108/SR J-04-2014-0050

Wanderley, L. S. O., Lucian, R., Farache, F., \& de Sousa Filho, J. M. (2008). CSR Information Disclosure on the Web: A Context-Based Approach Analysing the Influence of Country of Origin and Industry Sector. Journal of Business Ethics, 82(2), 369-378. DOI: $10.1007 / \mathrm{s} 10551-008-9892-z$

Zubeltzu-Jaka, E., Andicoechea-Arondo, L., \& Alvarez-Etxeberria, I. (2018). Corporate social responsibility and corporate governance and corporate financial performance: Bridging concepts for a more ethical business model. Business Strategy \& Development, 1/3), 214222. DOI:10.1002/bsd2.29

\section{AUTHORS' CONTRIBUTIONS}

\begin{tabular}{|l|c|c|c|c|}
\hline \multicolumn{1}{|c|}{ Contributions } & $\begin{array}{c}\text { Alan } \\
\text { Bandeira } \\
\text { Pinheiro }\end{array}$ & $\begin{array}{c}\text { Thicia Stela } \\
\text { Lima } \\
\text { Sampaio }\end{array}$ & $\begin{array}{c}\text { Daniel } \\
\text { Barboza } \\
\text { Guimarães }\end{array}$ & $\begin{array}{c}\text { Sílvia Maria } \\
\text { Dias Pedro } \\
\text { Rebouças }\end{array}$ \\
\hline $\begin{array}{l}\text { 1. Idealization and conception of the } \\
\text { research subject and theme }\end{array}$ & $\checkmark$ & & & \\
\hline 2. Definition of the research problem & $\checkmark$ & & & \\
\hline 3. Development of Theoretical Platform & $\checkmark$ & & & \\
\hline $\begin{array}{l}\text { 4. Design of the research } \\
\text { methodological approach }\end{array}$ & $\checkmark$ & $\checkmark$ & $\checkmark$ & $\checkmark$ \\
\hline $\begin{array}{l}\text { 5. Data collection } \\
\text { 6. Analyses and interpretations of } \\
\text { collected data }\end{array}$ & $\checkmark$ & $\checkmark$ & & \\
\hline 7. Research conclusions & $\checkmark$ & $\checkmark$ & & $\checkmark$ \\
\hline 8. Critical review of the manuscript & $\checkmark$ & & & \\
\hline $\begin{array}{l}\text { 9. Final writing of the manuscript, } \\
\text { according to the rules established by } \\
\text { the Journal. }\end{array}$ & $\checkmark$ & $\checkmark$ & $\checkmark$ & $\checkmark$ \\
\hline 10. Research supervision & & & $\checkmark$ & $\checkmark$ \\
\hline
\end{tabular}

